\title{
Phytochemical analysis and antioxidant capacity of Tabernaemontana catharinensis A. DC. Fruits and branches
}

\author{
MARIANA PIANA ${ }^{1}$, ALINE A. BOLIGON ${ }^{1}$, THIELE F. DE BRUM ${ }^{1}$, MARINA ZADRA ${ }^{1}$, \\ BIANCA V. BELKE ${ }^{1}$, AMANDA L.F. FROEDER ${ }^{1}$, JANAÍNA K. FROHLICH ${ }^{1}$, LETÍCIA T. NUNES ${ }^{1}$, \\ LAUREN PAPPIS ${ }^{1}$, ALEXANDRA A. BOLIGON ${ }^{2}$ and MARGARETH L. ATHAYDE ${ }^{1}$ \\ ${ }^{1}$ Laboratório de Fitoquímica, Departmento de Farmácia Industrial, Universidade Federal de Santa Maria, \\ Av. Roraima, 26, sala 1115, 97105-900 Santa Maria, RS, Brasil \\ ${ }^{2}$ Universidade Federal do Pampa, Departamento de Fitotecnia, Campus São Gabriel, \\ Av. Antonio Trilha, 1847, 97300-000 São Gabriel, RS, Brasil
}

Manuscript received on December 6, 2012; accepted for publication on November 26, 2013

\begin{abstract}
The antioxidant capacity of the crude extract and fractions of Tabernaemontana catharinensis fruits and branches, was evaluated by the 2,2-diphenyl-1-picrylhydrazyl (DPPH) method and the content of polyphenols, flavonoids, alkaloids and condensed tannins were determined by the spectrophotometric method. The ethyl acetate fraction of the fruits and the n-butanol fraction of the branches showed $\mathrm{IC}_{50}$ of $181.82 \mu \mathrm{g} / \mathrm{mL}$ and $78.19 \mu \mathrm{g} / \mathrm{mL}$, respectively. All fractions were analyzed by high performance liquid chromatography (HPLC), in the branches were quantified chlorogenic acid in the chloroform $(8.96 \mathrm{mg} / \mathrm{g})$, ethyl acetate $(4.31 \mathrm{mg} / \mathrm{g})$ and n-butanol $(3.33 \mathrm{mg} / \mathrm{g})$ fractions; caffeic acid in the ethyl acetate $(5.24 \mathrm{mg} / \mathrm{g})$ and n-butanol $(1.81 \mathrm{mg} / \mathrm{g})$; gallic acid $(0.52 \mathrm{mg} / \mathrm{g})$ in the n-butanol. In the fruits, chlorogenic acid in the chloroform $(1.67 \mathrm{mg} / \mathrm{g})$; rutin in the ethyl acetate $(3.45 \mathrm{mg} / \mathrm{g})$ and n-butanol $(8.98 \mathrm{mg} / \mathrm{g})$ fractions. The present study showed that these quantified compounds can contribute to antioxidant capacity which was higher in the branches than in the fruits.
\end{abstract}

Key words: antioxidant capacity, apocynaceae, chlorogenic acid, Tabernaemontana catharinensis.

\section{INTRODUCTION}

Currently there is great interest in finding natural antioxidants from plant materials. Numerous crude extracts and pure natural compounds from plants were reported to have antioxidant and radicalscavenging activities (Boligon et al. 2009, Chang and Sung 2008). The use of these compounds, such as flavonoids and other phenolic compounds present in most plants has been associated with a lower incidence of diseases related to the oxidative stress (Behera et al. 2008, Hajji et al. 2010), such

Correspondence to: Margareth Linde Athayde

E-mail:marga@ccs.ufsm.br as cancer, heart diseases and neurodegenerative diseases (Hajji et al. 2010, Mustafa et al. 2010).

Tabernaemontana catharinensis A. DC., Apocynaceae, (Syns. Peschiera catharinensis A. DC) has also been denoted as Tabernaemontana affins, Tabernaemontana australis and Tabernaemontana hilariana (Rates et al. 1993, Soares et al. 2007), and can be found in Argentina, Paraguay, Brazil and Bolivia (Leeuwenberg 1994, Pereira et al. 2008). Popularly it is known as "jasmin" (jasmine), "leiteira de dois irmãos" (milkweed) and "cascade-cobra" (snake skin) (Pereira et al. 2005, Rates et al. 1993). The tea or infusion of T. catharinensis 
is used in popular medicine as an antiinflammatory (Pereira 2003), as an antidote for snake bites, to relieve toothache, as a vermifuge and also to eliminate warts (Pereira et al. 2005, Rates et al. 1993). The essential oil of the plant leaves showed antioxidant activity (Boligon et al. 2012).

Many studies performed with plants resulted in the development of natural antioxidant formulations. However, there is not enough scientific information about antioxidant properties of various plants, especially those which are less used in medicine. So it is an interesting and useful task to find new sources of natural antioxidants. In this study, the total amount of polyphenols, flavonoids, alkaloids and condensed tannins present in the crude extract and chloroform fraction (CRF), ethyl acetate fraction (EtAc) and n-butanol fraction $(\mathrm{n}-\mathrm{BuOH})$ of $T$. catharinensis fruits and branches, were determined. Simultaneously, HPLC/DAD was performed to identify which were the mainly phenolics compounds and to quantify them.

\section{MATERIALS AND METHODS}

\section{CHEMicals}

All chemicals were of analytical grade. The solvents for the extractions and analytical procedures as chloroform, ethyl acetate, ethanol, n-butanol, gallic acid, chlorogenic acid and a spectrophotometric grade methanol were purchased from Merck (Darmstadt, Germany). Folin-Ciocalteau reagent 2 N, DPPH radical (1,1-diphenyl-2-picrylhydrazyl), rutin, caffeic acid, and catechin were acquired from Sigma Chemical Co. (St. Louis, MO, USA). All other chemicals and reagents were purchased locally and were of analytical grade.

\section{PLANT COLLECTION AND EXTRACTIONS}

Branches and fruits of $T$. catharinensis were collected in São Miguel (Rio Grande do Sul, a state in the south of Brazil) in December/2009. A dried voucher specimen is preserved in the herbarium of the Department of Biology at Federal University of Santa Maria (SMBD 12.355). The branches of the plant were dried at room temperature and chopped in a knife mill. The chopped branches and fruits in natura were macerated separately at room temperature with ethanol $70 \%$ for a week daily agitated. After filtration, both extracts were evaporated under reduced pressure to remove the ethanol. Equal parts of aqueous extract (fruits and branches) were subjected to dryness to obtain the crude extract and another part of each extract was suspended in water and partitioned successively with chloroform, ethyl acetate and n-butanol $(3 \mathrm{x}$ $200 \mathrm{~mL}$ for each solvent), after the three fractions were subjected to dryness.

\section{ANALYSIS OF POLYPHENOLS, FLAVONOIDS, ALKALOIDS AND}

CONDENSED TANNINS AND ANTIOXIDANT CAPACITY

The analysis of the crude extract and of the different fractions of fruits and branches of $T$. catharinensis were performed in a Shimadzu UV1201 spectrophotometer (Shimadzu, Kyoto, Japan) in triplicates.

\section{Polyphenols analysis}

The polyphenols contents were determined by the Folin-Ciocalteu method, described by Chandra and De Mejia (2004). The absorbance was $730 \mathrm{~nm}$, measured in spectrophotometer. The data were expressed in mg gallic acid equivalent (GAE) per g of each fraction, based on the calibration curve of gallic acid.

\section{Flavonoid analysis}

The flavonoid content was determined by the reaction with aluminum chloride using the method described by Woisky and Salatino (1998). The absorbance was $420 \mathrm{~nm}$, measured in spectrophotometer. The data was calculated based on calibration curve of rutin and expressed in $\mathrm{mg}$ equivalents of rutin (RE) per $g$ of each fraction. 


\section{Condensed tannins analysis}

Condensed tannins were determined by Morrison's method et al. (1995) which uses vanillin as a reagent. The absorbance was $500 \mathrm{~nm}$, measured in spectrophotometer. The data were expressed in mg catechin equivalent (CE) per $g$ of each fraction, based on calibration curve of catechin.

\section{Alkaloids analysis}

Alkaloids were determined by reaction of precipitated with dragendorff's reagent, described by Sreevidya and Mehrotra (2003). The absorbance was $435 \mathrm{~nm}$, measured in spectrophotometer. The data was calculated based on calibration curve of Bismuth nitrate and expressed in $\mathrm{mg}$ of alkaloids per $\mathrm{g}$ of each fraction.

\section{Radical-scavenging capacity - DPPH assay}

The antioxidant capacity was evaluated following the method described by Choi et al. (2002). The Spectrophotometric analysis was used in order to determine the inhibition concentration $\left(\mathrm{IC}_{50}\right.$ concentration which gives $50 \%$ inhibition) of the crude extract and fractions. Six different ethanol dilutions of the crude extract and fractions $(2.5 \mathrm{~mL})$, at $250 ; 125 ; 62.5 ; 31.25 ; 15.62$ and $7.81 \mu \mathrm{g} / \mathrm{mL}$ were added to $1.0 \mathrm{~mL}$ of a $0.3 \mathrm{mM}$ DPPH ethanol solution. The absorbance was measured at $518 \mathrm{~nm}$ by spectrophotometer against a blank after $30 \mathrm{~min}$ of reaction at room temperature. DPPH solution $(1.0 \mathrm{~mL})$ plus ethanol $(2.5 \mathrm{~mL})$ was used as a control. IP\% (percentage of inhibition) was plotted against the sample concentration, and a linear regression curve was established in order to calculate the $\mathrm{IC}_{50}$.

HPLC SYSTEM FOR ANALYSIS OF PHENOLIC COMPOUNDS

The identifications and assays were performed using the method described by Evaristo and Leitão (2001) with slight modifications. High performance liquid chromatography was performed with the HPLC system (Shimadzu, Kyoto, Japan), Prominence AutoSampler (SIL-20A), equipped with Shimadzu LC-20 AT reciprocating pumps connected to the degasser
DGU 20A5 with integrator CBM 20A, UV-VIS detector DAD SPD-M20A and Software LC solution 1.22 SP1. Reverse phase chromatographic analyses were carried out under gradient, conditions using a C-18 column ( $4.6 \mathrm{~mm} \times 250 \mathrm{~mm}$ ) packed with 5 $\mu \mathrm{m}$ diameter particles; the mobile phase A was water containing $2.0 \%$ acetic acid and mobile phase B was methanol. The mobile phase was filtered through a $0.45 \mu \mathrm{m}$ membrane filter and then degassed by an ultrasonic bath prior to use. Standard reference solutions of caffeic acid and chlorogenic acid were prepared in the HPLC mobile phase at a concentration range of $0.00625-0.250 \mathrm{mg} / \mathrm{mL}$, gallic acid and rutin at a concentration range of $0.0031-0.250 \mathrm{mg} /$ $\mathrm{mL}$. The fractions and extracts were also dissolved in the mobile phase. All solutions and samples were first filtered through a $0.45 \mu \mathrm{m}$ membrane filter (Millipore). The chromatographic peaks were confirmed by comparing their retention time and Diode-Array-UV spectra with those of the reference standards. Isolated compounds were quantified at $325 \mathrm{~nm}, 327 \mathrm{~nm}, 271 \mathrm{~nm}$, and $356 \mathrm{~nm}$. The flow rate was $0.8 \mathrm{~mL} / \mathrm{min}$ and the injection volume was $40 \mu 1$. All chromatographic operations were carried out at room temperature and in triplicates.

\section{STATISTICAL ANALYSES}

One-way ANOVA followed by Tukey test were performed in the total phenolics, flavonoids, alkaloids, condensed tannins and DPPH assays. Statistical $p$ values were calculated to quantify levels of significance for each treatment type. A significant $p$ value ( $p<0.001$ when appropriate) means that there exists significant difference between the two sets of data being analyzed.

\section{RESULTS AND DISCUSSION}

The content of polyphenols, flavonoids, alkaloids and condensed tannins of the crude extract and its different fractions from the fruits and branches of T. catharinensis are shown in table I and II, respectively. 
TABLE I

$\mathrm{IC}_{50}$ and total of polyphenols, flavonoids, alkaloids and condensed tannins in the crude extract and in the fractions of fruits of $T$. catharinensis.

Results are expressed as mean of three determinations \pm RSD (relative standard deviation); averages followed by different letters in each column differ by Tukey test at $\mathbf{p}<\mathbf{0 . 0 0 1}$.

\begin{tabular}{cccccc}
\hline $\begin{array}{c}\text { Fractions } \\
\text { and crude } \\
\text { extract }\end{array}$ & $\begin{array}{c}\mathbf{I C}_{\mathbf{5 0}} \\
(\boldsymbol{\mu g} / \mathbf{m L})\end{array}$ & $\begin{array}{c}\text { Polyphenols } \\
\text { (mg GAE/g dry } \\
\text { extract) }\end{array}$ & $\begin{array}{c}\text { Flavonoids } \\
\text { (mg RE/g dry } \\
\text { extract) }\end{array}$ & $\begin{array}{c}\text { Alkaloids } \\
\text { (mg of alkaloids/g dry } \\
\text { extract) }\end{array}$ & $\begin{array}{c}\text { Condensed tannins } \\
\text { (mg CE/ g dry } \\
\text { extract) }\end{array}$ \\
\hline $\mathrm{CRF}$ & $266.55 \pm 1.57 \mathrm{~b}$ & $311.52 \pm 0.9 \mathrm{a}$ & $154.73 \pm 1.74 \mathrm{~b}$ & $91.48 \pm 1.77 \mathrm{a}$ & $3.11 \pm 0.40 \mathrm{~b}$ \\
$\mathrm{EtAc}$ & $181.82 \pm 1.05 \mathrm{c}$ & $221.12 \pm 1.64 \mathrm{~b}$ & $218.81 \pm 1.08 \mathrm{a}$ & $18.44 \pm 1.92 \mathrm{~b}$ & $5.51 \pm 0.40 \mathrm{a}$ \\
$\mathrm{n}-\mathrm{BuOH}$ & $188.24 \pm 0.68 \mathrm{c}$ & $111.97 \pm 0.09 \mathrm{c}$ & $119.07 \pm 1.30 \mathrm{~b}$ & $16.41 \pm 0.72 \mathrm{~b}$ & $0.53 \pm 0.67 \mathrm{c}$ \\
Crude extract & $1155.91 \pm 0.64 \mathrm{a}$ & $71.03 \pm 0.2 \mathrm{~d}$ & $41.30 \pm 1.08 \mathrm{c}$ & $6.84 \pm 1.58 \mathrm{c}$ & $1.42 \pm 0.68 \mathrm{bc}$ \\
\hline
\end{tabular}

The results showed that for fruits, the amount of polyphenols for CRF fraction was the highest one (311.52 mg GAE/g of fraction), followed by EtAc fraction and $\mathrm{n}-\mathrm{BuOH}$ fraction. A similar tendency was not observed with the same fractions of branches, which showed that the EtAc fraction had the highest amount of polyphenols (397.94 mg GAE/g of fraction), followed by the $n-\mathrm{BuOH}$ fraction and the CRF fraction. In the crude extract of fruits and branches, it was observed that they had a lower polyphenol's content when compared to all the other fractions. Variations in the amount of polyphenol's in the different fractions may be attributed to the polarities of the compounds present in the plant (Hajji et al. 2010); phenolic compounds are usually extracted from the more polar fractions (Tian et al. 2011), for this reason we found higher concentrations of these compounds in the EtAc and $\mathrm{n}-\mathrm{BuOH}$ fractions from the branches.

With regards to the flavonoids, the results showed that the CRF fraction of branches of $T$. catharinensis had the highest amount of flavonoids (180.46 $\mathrm{mg}$ of rutin equivalents (RE)/g of fraction), followed by the EtAc fraction, $\mathrm{n}-\mathrm{BuOH}$ fractions and the crude extract. However for fruits, the EtAc fractions had the highest amount of flavonoids (218.81 mg RE/g of fraction), followed by the $\mathrm{CRF}$ fraction, $\mathrm{n}-\mathrm{BuOH}$ fraction and the crude extract.
The highest amount of alkaloids was found in the CRF fractions, for both parts of the plant, $179.10 \mathrm{mg}$ of alkaloids/g of fraction in branches and $91.48 \mathrm{mg}$ of alkaloids/g of fraction in fruits. Chloroform solvent is commonly used for the extraction of alkaloids, such as in studies performed by Pereira et al. (2005) and Rates et al. (1988) with T. Catharinensis, explaining the large amount of alkaloids in this fraction.

The results showed that there is a small amount of condensed tannins in fruits and branches of this species. Studies performed by Wong et al. (2011) found tannins in methanol extracts of leaves of Vallaris glabra, Apocynaceae.

The DPPH radical scavenging capacity of samples were dose-dependent, and the branches obtained better antioxidant capacity (AC) than fruits. For fruits, it was observed that the more polar fractions, EtAc and $\mathrm{n}-\mathrm{BuOH}$, had higher scavenging capacity toward DPPH with the $\mathrm{IC}_{50}$ values of $181.82 \mu \mathrm{g} / \mathrm{mL}$ and $188.24 \mu \mathrm{g} / \mathrm{mL}$ respectively (table I), and these same fractions showed superior amounts of flavonoids. Many studies have shown that the antioxidants compounds are more easily extracted by polar solvents due to the presence of hydroxyls (Mensor et al. 2001).

For branches, the $\mathrm{n}-\mathrm{BuOH}$ fractions exhibited high scavenging activity toward DPPH with the $\mathrm{IC}_{50}$ of $78.19 \mu \mathrm{g} / \mathrm{mL}$, followed by the CRF fraction (table II). This result cannot be associated to the polyphenol content and although the amounts of 
condensed tannins follow the same tendency of the $\mathrm{AC}$, one cannot say that these are the main responsible for the $\mathrm{AC}$, because they were found in small quantities. In addition, large quantities of alkaloids were found in the CRF fraction, which may have contributed, at least in part, to the great $\mathrm{AC}$ of this fraction, since it showed the second best $\mathrm{IC}_{50}$ of $93.11 \mu \mathrm{g} / \mathrm{mL}$.

TABLE II

$\mathrm{IC}_{50}$ and total of polyphenols, flavonoids, alkaloids and condensed tannins

in the crude extract and in the fractions of the branches of $T$. catharinensis.

Results are expressed as mean of three determinations \pm RSD (relative standard deviation); averages followed by different letters in each column differ by Tukey test at $\mathbf{p}<0.001$.

\begin{tabular}{cccccc}
\hline $\begin{array}{c}\text { Fractions and } \\
\text { crude extract }\end{array}$ & $\begin{array}{c}\mathbf{I C}_{\mathbf{5 0}} \\
(\boldsymbol{\mu g} / \mathbf{m L})\end{array}$ & $\begin{array}{c}\text { Polyphenols } \\
(\mathbf{m g} \text { GAE/g dry } \\
\text { extract) }\end{array}$ & $\begin{array}{c}\text { Flavonoids (mg } \\
\text { RE/g dry extract) }\end{array}$ & $\begin{array}{c}\text { Alkaloids (mg of } \\
\text { alkaloids/g dry } \\
\text { extract) }\end{array}$ & $\begin{array}{c}\text { Condensed tannins } \\
\text { (mg CE/g dry } \\
\text { extract) }\end{array}$ \\
\hline $\mathrm{CRF}$ & $93.11 \pm 1.55 \mathrm{~b}$ & $191.50 \pm 2.0 \mathrm{c}$ & $180.46 \pm 1.77 \mathrm{a}$ & $179.10 \pm 1.53 \mathrm{a}$ & $2.66 \pm 0.25 \mathrm{ab}$ \\
$\mathrm{EtAc}$ & $106.27 \pm 1.18 \mathrm{~b}$ & $397.94 \pm 1.39 \mathrm{a}$ & $163.51 \pm 1.44 \mathrm{~b}$ & $29.57 \pm 1.27 \mathrm{c}$ & $2.33 \pm 0.40 \mathrm{ab}$ \\
$\mathrm{n}-\mathrm{BuOH}$ & $78.19 \pm 0.54 \mathrm{c}$ & $248.70 \pm 1.92 \mathrm{~b}$ & $156.28 \pm 1.71 \mathrm{~b}$ & $58.20 \pm 1.02 \mathrm{~b}$ & $3.10 \pm 0.17 \mathrm{a}$ \\
Crude extract & $202.17 \pm 1.51 \mathrm{a}$ & $42.47 \pm 1.41 \mathrm{~d}$ & $39.54 \pm 1.17 \mathrm{c}$ & $11.02 \pm 1.99 \mathrm{~d}$ & $1.67 \pm 0.98 \mathrm{~b}$ \\
\hline
\end{tabular}

The large variations of the AC may be related not only to the flavonoids contribution, but certainly is related to the presence of different types of flavonoids.

Generally, the AC of flavonoids is dependent of the structure and of the substitution pattern of hydroxyl groups. The essential requirement for an effective radical scavenging activity is the 3, 4-orthodihydroxy configuration in ring $\mathrm{B}$ and 4-carbonyl group in ring $\mathrm{C}$, which has the best electron donating properties and a radical target. The presence of 3-OH group or 3 and $5-\mathrm{OH}$ groups, giving a catechol-like structure in ring $\mathrm{C}$, which is also beneficial for the antioxidant activity of flavonoids. Removal of the 3-OH will affect the conformation of the molecule by the reduction of the number of $\mathrm{OH}$ group. The presence of $\mathrm{C} 2-\mathrm{C} 3$ double bond configured with a 4-keto arrangement was known to be responsible for electron delocalization from ring $\mathrm{B}$ and it increases the radical scavenging activity (Mustafa et al. 2010, Wojdyło et al. 2007). Another important factor is the glycosylation in all these crucial positions hydroxyl influences the antioxidant activity of flavonoids such changes of the hydroxyl groups by glycosylation decreases the antioxidant activity. Flavonoids often occur as glycosides, glycosylation rendering the molecule less reactive to free radicals and more soluble in water (Rice-Evans et al. 1997).
Distinct association between the bioactive compounds and antioxidant capacity might be related to the presence of various active compounds in the plant, which resulted in different trends of AC (Jayaprakasha and Patil 2007, Mustafa et al. 2010). Among the partitions, the more polar ones (EtAc and $\mathrm{n}-\mathrm{BuOH}$ fraction) were those that generally had better AC. Consequently, the smallest $\mathrm{AC}$ was found in the less polar partitions, it was demonstrated in the different fractions of the fruits.

The fractions were analyzed by HPLC. Chloroform fraction of the branches showed 8.96 $\pm 0.47 \mathrm{mg}$ of chlorogenic acid/g of fraction (figure 1), the EtAc fraction $4.31 \pm 0.55 \mathrm{mg}$ of chlorogenic $\mathrm{acid} / \mathrm{g}$ and $5.24 \pm 0.71 \mathrm{mg}$ of caffeic $\mathrm{acid} / \mathrm{g}$, the $\mathrm{n}$-BuOH fraction $3.33 \pm 0.51 \mathrm{mg}$ of chlorogenic $\mathrm{acid} / \mathrm{g}, 1.81 \pm 0.74 \mathrm{mg}$ of caffeic acid/g and 0.52 $\pm 0.1 \mathrm{mg}$ of gallic acid/g of fraction (figure 2). Concerning the fruits, the CRF fraction showed $1.67 \pm 0.36 \mathrm{mg}$ of chlorogenic acid/g of fraction, whereas in the EtAc fraction was possible to quantify rutin $(3.45 \pm 1.66 \mathrm{mg} / \mathrm{g}$ of fraction, figure 3$)$. The $\mathrm{n}-\mathrm{BuOH}$ fraction presented $8.98 \pm 0.34 \mathrm{mg}$ of rutin/g of fraction (figure 4). These quantified compounds can contribute positively for the antioxidant capacity of this species. 


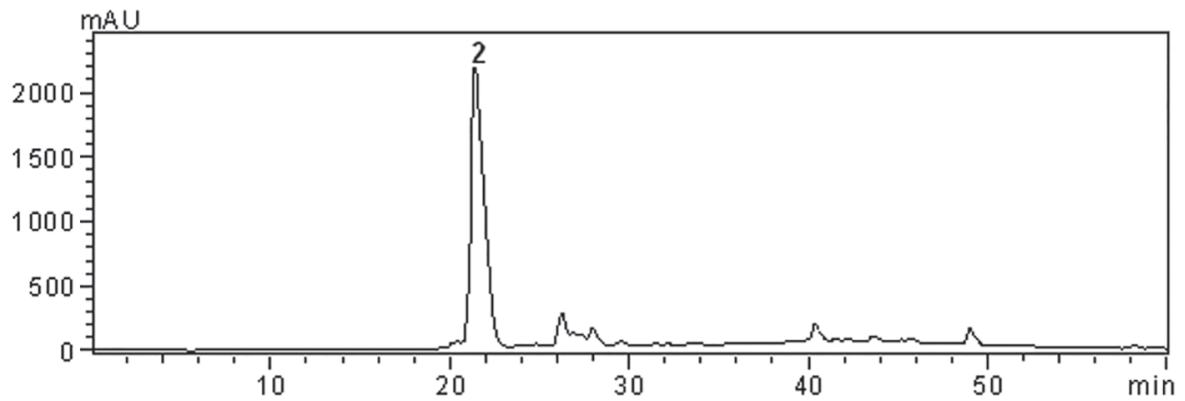

Figure 1 - HPLC analysis of chlorogenic acid (2) of the CRF fraction of the branches.

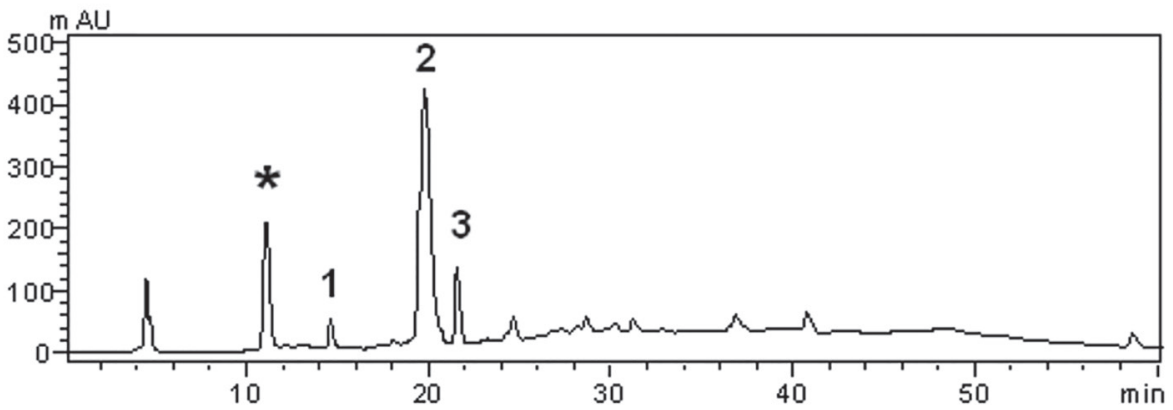

Figure 2 - HPLC analysis of gallic acid (1), chlorogenic acid (2), and caffeic acid (3) of the $\mathrm{n}-\mathrm{BuOH}$ fraction of the branches, $(*)$ unknown peak.

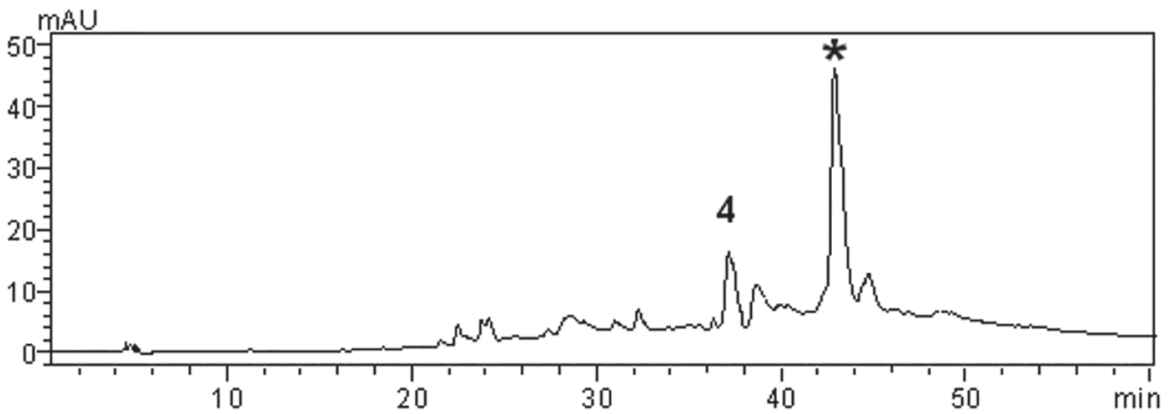

Figure 3 - HPLC analysis of rutin (4) of the EtAc fraction of the fruits, $(*)$ unknown peak.

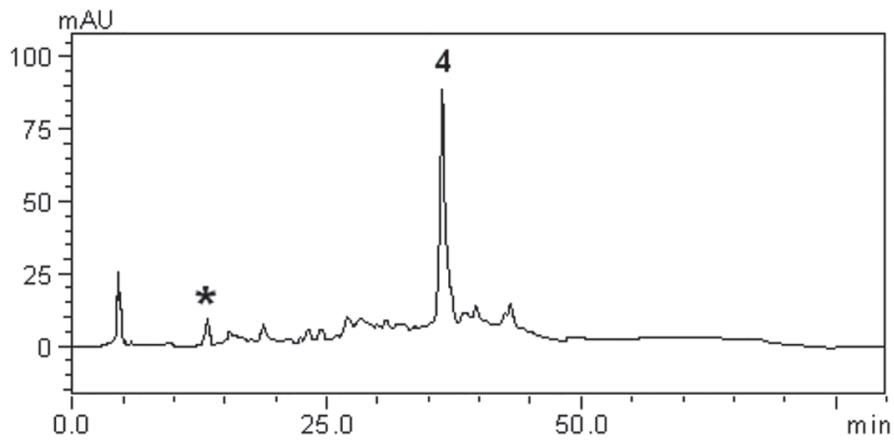

Figure 4 - HPLC analysis of rutin (4) of the n-BuOH fraction of the fruits, (*) unknown peak. 


\section{CONCLUSION}

The branches had higher antioxidant capacity than fruits. The EtAc and $\mathrm{n}-\mathrm{BuOH}$ fractions of the fruits, and the $\mathrm{n}-\mathrm{BuOH}$ and $\mathrm{CRF}$ fractions of the branches showed higher antioxidant capacities, these results may be related to the quantity, structure and substitution pattern of hydroxyl groups of flavonoids. Besides rutin, a glycoside of quercetin and chlorogenic acid, both recognized as active antioxidants, caffeic acid may also contribute with this capacity.

\section{ACKNOWLEDGMENTS}

The authors thank the financial support of Conselho Nacional de Desenvolvimento Científico e Tecnológico (CNPq, Brazil) and Fundação de Amparo à Pesquisa do Estado do Rio Grande do Sul (FAPERGS, Brazil).

\section{RESUMO}

A capacidade antioxidante do extrato bruto e frações dos frutos e ramos de Tabernaemontana catharinensis, foi avaliada pelo método do 2,2-difenil-1-picril hidrazil $(\mathrm{DPPH})$ e o conteúdo de polifenóis, flavonoides, alcaloides e taninos condensados foram determinados pelos métodos espectrofotométricos. A fracção de acetato de etila dos frutos e a fração n-butanol dos ramos mostraram $\mathrm{IC}_{50}$ de $181,82 \mu \mathrm{g} / \mathrm{mL}$ e $78,19 \mu \mathrm{g} / \mathrm{mL}$, respectivamente. Todas as frações foram analisadas por cromatografia líquida de alta eficiência (HPLC), nos ramos foram quantificados ácido clorogênico na fração clorofórmica $(8,96 \mathrm{mg} / \mathrm{g})$, acetato de etila $(4,31 \mathrm{mg} / \mathrm{g})$ e n-butanol (3,33 mg/g); ácido cafeico na acetato de etila $(5,24 \mathrm{mg} / \mathrm{g})$ e n-butanol (1,81 mg/g); ácido gálico $(0,52$ $\mathrm{mg} / \mathrm{g}$ ) na n-butanol. Nos frutos, ácido clorogênico, na fração clorofórmica $(1,67 \mathrm{mg} / \mathrm{g})$; rutina na acetato de etila $(3,45 \mathrm{mg} / \mathrm{g})$ e $\mathrm{n}$-butanol $(8,98 \mathrm{mg} / \mathrm{g})$. O presente estudo mostrou que esses compostos quantificados podem contribuir na capacidade antioxidante que foi maior nos ramos do que nos frutos.

Palavras-chave: capacidade antioxidante, apocynaceae, ácido clorogênico, Tabernaemontana catharinensis.

\section{REFERENCES}

Behera BC, Verma N, Sonone A And Makhija U. 2008. Antioxidant and antibacterial properties of some cultured lichens. Bioresour Technol 99: 776-784.

Boligon AA, Pereira RP, Feltrin AC, Machado MM, JANOVIK V, RochA JBT AND ATHAYDE ML. 2009. Antioxidant activities of flavonol derivatives from the leaves and stem bark of Scutia buxifolia Reiss. Bioresour Technol 100: 6592-6598.

Boligon AA, Schwanz TG, Piana M, BANDEIRA RV, FROHLICH JK, BRUM TF, ZADRA M AND ATHAYDE ML. 2012. Chemical composition and antioxidant activity of the essential oil of Tabernaemontana catharinensis A. DC. leaves. Nat Prod Res, p. 68-71.

Chandra S AND DE MeJIA EG. 2004. Polyphenolic compounds, antioxidant capacity and quinone reductase activity of an aqueous extract of Ardisia compressa in comparision to Mate (Ilex paraguaiensis) and Green (Camellia sinensis) Teas. J Agric Food Chem 52: 3583-3589.

CHANG SK AND SUNG PM. 2008. Antioxidant activities of ethanol extracts from seeds in fresh Bokbunja (Rubus coreanus Miq.) and wine processing wast. Bioresour Technol 99: 4503-4509.

Choi CW, Kim SC, Hwang SS, Choi BK, Ahn HJ, LeE MY, PARK SH AND KIM SK. 2002. Antioxidant activity and free radical scavenging capacity between Korean medicinal plants and flavonoid by assay-guided comparision. Plant Science 163: 1161-1168.

EVARISTO IM AND LEITÃo MC. 2001. Identificação e quantificação por DAD-HPLC, da fracção fenólica contida em folhas de Quercus suber L. Silva Lusitana 9: 135-141.

HAJJI M, JARRAYA R, LASSOUED I, MASMOUdi O, DAMAK M AND NASRI M. 2010. GC/MS and LC/MS analysis, and antioxidant and antimicrobial activities of various solvent extracts from Mirabilis jalapa tubers. Process biochem 45: 1486-1493.

JAYAPRAKASHA GK AND PATIL BS. 2007. In vitro evaluation of the antioxidant activities in fruit extracts from citron and blood orange. Food Chem 101: 410-418.

LEEUWENBERG AJM. 1994. A revision of Tabernaemontana. The new world species and Stemmadenia, The Royal Botanic Gardens: Kew 17: 213-450.

Mensor LL, Menezes FS, Leitão GG, Reis AS, SAntos TC, COUBE CS AND LeITÃo SG. 2001. Screening of Brazilian plant extracts for antioxidant activity by the use of DPPH free radical method. Phytother Res 15: 27-30.

Morrison IM, Asiedu EA, STUChBURy T ANd Powell AA. 1995. Determination of lignin and tannin contents of Cowpea seed coats. Ann Bot 76: 287-290.

Mustafa RA, Hamid AA, MOHAMEd S AND BAKAR FA. 2010. Total phenolic compounds, flavonoids, and radical scavenging activity of 21 Selected Tropical Plants. J Food Sci 75: 28-30.

PEREIRA CG. 2003. SFE of pharmacological compounds from Tabernaemontana catharinensis: analysis of the antioxidant and antimycobacterial activity. $6^{\text {th }}$ Int Symp on Supercritical Fluids 1: 195-200. 
Pereira CG, Leal PF, SATo DN AND Meireles MAA. 2005. Antioxidant and antimycobacterial activities of Tabernaemontana catharinensis extracts obtained by supercritical $\mathrm{CO}_{2}+$ cosolvent. J Med Food 8: 533-538.

Pereira PS, França SC, Oliveira PVA, Breves CMS, Pereira SIV, Sampaio SV, Nomizo A and Dias DA. 2008. Chemical constituents from Tabernaemontana catharinensis root bark: a brief NMR review of indole alkaloids and in vitro cytotoxicity. Quim Nova 31: 20-24.

Rates SMK, CAUduro AD, SAlazar V, Moreno PRH AND HENRIQUES AT. 1988. Alcalóides indólicos em Peschiera australis (Muell. Arg.) Miers. Var. australis. Cad Farm 4: 51-62.

RATES SMK, SChapoval EES, SOUZA IA AND HENRIQUES AT. 1993. Chemical constituents and pharmacological activities of Peschiera australis. Int J Pharmacogn 31: 288-294.

Rice-Evans CA, Miller NJ AND Paganga G. 1997. Antioxidant properties of phenolic compounds. Trends Plant Sci 2: 152-159.

SoARES DC, Pereira CG, MEIREles MAA AND SARAIVA EM. 2007. Leishmanicidal activity of a supercritical fluid fraction obtained from Tabernaemontana catharinensis. Parasitol Int 56: 135-139.
SREEVIDYA N AND MEHROTRA S. 2003. Spectrophotometric method for estimation of alkaloids precipitable with dragendorff's reagent in plant materials. J AOAC Int 86: 1124-1127.

Tian S, ShI Y, ZHOU X, GE L AND UpU H. 2011. Total polyphenolic (flavonoids) content and antioxidant capacity of different Ziziphora clinopodioides Lam. Extracts. Pharmacogn Mag 7: 65-68.

WoISKY RG AND SALATINO A. 1998. Analysis of própolis: some parameters and procedures for chemical quality control. J Api Res 37: 99 -105.

WOJDYŁo A, OSZMIASKI J AND CZEMERYS R. 2007. Antioxidant activity and phenolic compounds in 32 selected herbs. Food Chem 105: 940-949.

Wong SK, LiM YY, ABDULlaH NR AND Nordin FJ. 2011. Assessment of antiproliferative and antiplasmodial activities of five selected Apocynaceae species. BMC Complement Altern Med 11: 1-8. 